\title{
The Role of Principal in Implementing the 2013 Curriculum-Based Learning at SMP Negeri 6 Unggul Sekayu Musi Banyuasin Regency
}

\author{
Supriadi $^{\left.1^{*}\right)}$, Yasir Arafat ${ }^{2}$, Syaiful Eddy ${ }^{2}$ \\ ${ }^{I}$ SD Negri Balin Musi Banyuasin \\ ${ }^{2}$ Universitas PGRI Palembang \\ *Corresponding author.Email: asupri105@gmail.com
}

\begin{abstract}
This article aimed to determine and describe the role of the principal in implementing the 2013 curriculum learning in SMP Negeri 6 Unggul Sekayu, Musi Banyuasin Regency. This research was descriptive qualitative. Data collection was carried out through observation, interviews, and documentation. The data were analyzed through four steps comprising data collection, data reduction, data presentation, and drawing conclusions. The results showed that principal in implementing the 2013 Curriculum; 1) mapped the quality of learning through the 2013 Curriculum Implementation program, increasing the ability to teach teachers and creating a conducive school climate; 2) determined the 2013 curriculum implementation programs through vision and mission of the school; 3) improved the teaching quality of teachers; and 4) created conducive school climate.
\end{abstract}

Keywords: Role of the Principal, 2013 Curriculum Implementation, Junior High School Learning

\section{INTRODUCTION}

School is a system a process of interaction between school principals, teachers, employees, supervisors, school committees, and student takes place. The interaction process occurs as it is influenced by the organizational function, the motivation for authority, and the role model possessed by the principal as the leader, those are important influences in the formation of human resources. Good leadership and good work motivation will create a good working climate within an organization, in this case school [1]. The principal as an organizational leader must fulfill not only the main and supporting interests but also broader aspects since education is utilized by all groups [2][3].

In carrying out his role, the principal must consider the success of education in the respective school. By using targets, principals may overcome the low achievement of students. Nureva \& Melinda in his research suggests that one of the causes of the low quality of education in Indonesia is low learning achievement and no appropriate approach in teaching learning.[4] Furthermore, Ponidi, et al., (2020) argues that achievement is proof of academic success or students' ability in learning activities according to the using model learning, [5]
Educational issues, especially those related to the quality of education at present, are related to the implementation of the quality of educational processes and outcomes. The quality of education and the learning process needs to be harmonized with existing process standards. Process standards, as stated in the article (1) Government Regulation Number 19 of 2005 on National Education Standards, one of the standards that must be developed is process standard. Process standards are national education standards associated with the implementation of learning in educational units to achieve graduate competence, containing minimum criteria for the learning process in primary and secondary education across the jurisdiction of the Republic of Indonesia. Process standards include planning the learning process, implementing the learning process, assessing learning outcomes, and monitoring the learning process for an effective and efficient learning process [6].

Nowadays, the curriculum used in Indonesia is the 2013 Curriculum. The 2013 Curriculum is a substitute for the KTSP Curriculum (School-Based Curriculum), which details several aspects; knowledge, skills, and social and spiritual attitudes [7]. The 2013 Curriculum demands the optimum application of teaching and learning both for students and teachers. Teachers must 
possess competencies that cannot be abbreviated because those greatly affect the learning process. As stated by [8], the implementation in schools applying the 2013 Curriculum (K13) tends to information technology-based. In practice, there are many problems found such as the lack of facilities and infrastructure to support technology-based learning, teachers who are not familiar with the implementation of the 2013 Curriculum which focuses more on students' involvement, creativity, productivity, and critical thinking [9].

Therefore, the principal must exhibit an effective role so that the objective of the 2013 Curriculum can be achieved, which is to achieve effective and quality learning. As stated by Asnawan [10], the quality of education in schools will result in quality learning as a product of the effectiveness of the principal's leadership. Furthermore, Townsend, D \& Butterworth propose the determinants of quality education: [11] 1) the effectiveness of the principal's leadership style; 2) the sustainability of an effective teaching and learning process;[22] and 3) relevant curriculum.

Besides, in order to create effective and quality learning, the principal must encourage the implementation of a maximum of three main activities in classroom management: 1) creating an appropriate learning climate, including warmth and enthusiasm, challenges, variety, flexibility, emphasis on positivity things, and cultivation of self-discipline; 2) arranging the study room, including seating arrangement for students, setting up learning media; and 3) managing teaching and learning activities, comprising an opening and closing skills, explaining skills, questioning skills, encouraging skills, using learning media, guiding skills in small group discussion, class management skills, creating variety activities skills and teaching skill in an individual and small group [12].

Based on the results of preliminary observation, indicators found showed that teachers of SMP Negeri 6 Unggul Sekayu, Musi Banyuasin Regency had applied the 2013 Curriculum into the learning process. However, several problems were arising in implementing the 2013 Curriculum in the learning process, which are the substances of the 2013 Curriculum in the context of attitudes, knowledge, and skills which are very contrast to KTSP. Therefore, in implementing the 2013 Curriculum, teachers must create changes to the material in the KTSP to the 2013 Curriculum. This is an obstacle for teachers in implementing the 2013 Curriculum into the learning process at SMP Negeri 6 Sekayu.
To support the implementation of the 2013 Curriculum into learning, the principal must encourage teachers to participate in a training program related to the ability to develop the 2013 Curriculum in the learning process. Continuing training attended by teachers greatly influenced the ability of teachers to apply the 2013 Curriculum. In addition, the principal also strived to provide books related to the 2013 Curriculum to implement the 2013 Curriculum-based learning process run effectively.

Through an effective strategy, the principal will be able to carry out his role as much as possible to improve the quality and effectiveness of learning. OECD (2009: 87) states that learning leadership is effective if the principal plays his role in 1) monitoring teacher performance; 2) evaluating teacher performance; 3) implementing and arranging mentoring and training; 4) planning teacher's Sustainable Professional Development (PKB); 5) coordinating teamwork, and 6) coordinating collaborative learning[13].

Furthermore, the principal's duties as learning leaders are to 1) motivate teachers, 2) facilitate teachers to improve the quality of learning processes and outcomes, 3) provide good examples in preparing, implementing, and assessing learning 4 ) conduct frequent dialogues and discussions with teachers about the issues of quality of learning and efforts to solve them, 5) monitor the learning process in the classroom in a way that does not interfere with the learning process, 6) monitor teacher performance (supervise teachers), 7) assess teacher performance, 8) implement mentoring and training, 9) conduct teacher's sustainable professional development, 10) coordinate teamwork, and 11) coordinate collaborative learning. [14. The indicators for effective principal's leadership strategy include: 1) formulating concepts and implementation strategies; 2) establishing strategy; 3) determining targets to be achieved; and 4) consistently improving the quality of the process and student learning outcomes [15].

The principal's strategy to improve the quality of learning is to maximize his role as a leader who focuses on learning, in other words, successful leadership is one that supports teaching and learning success.

Salusu in [16] argues that implementation is the operation of various activities in order to achieve certain goals and cover all levels of management from top management to the bottom layer, which is the employee. Implementation according to Jones in [17] is the process of realizing a program to obtain results. Meanwhile, according to Horn and Meter in [17], implementation is an action taken by the government. Hence, 
implementation is an action taken after a policy is established. Implementation is a method for a policy to achieve its goals.

According to Cleaves, the implementation function also includes the creation of what in public policy subject is called a policy delivery system, consisting of certain methods or means that are specifically designed or arranged and directed towards the achievement of desired goals and objectives [18].

According to Law Number 20 of 2003 on the National Education System Article 1 point 19, the curriculum is a set of plans and arrangements regarding the objectives, content, and learning materials as well as methods used as guidelines for implementing learning activities to achieve certain educational goals. The curriculum is usually distinguished between the curriculum as a plan and a functional. The written plan is a curriculum document, whereas the curriculum that is applied in the classroom is a functional curriculum [19]. Based on the Regulation of Minister of Education and Culture Number 69 of 2013 on Basic Framework and Curriculum Structure of the Senior High School/ Islamic High School, the 2013 Curriculum comprises four core competencies which contain the objectives of the learning process. Those core competencies uses the following notation: 1) Core Competence-1 (KI-1) for spiritual attitudes; 2) Core Competencies-2 (KI-2) for social attitudes; 3) Core Competencies-3 (KI-3) for knowledge; and 4) Core Competencies-4 (KI-4) for skills. The 2013 Curriculum is a character and competency-based curriculum [20].

Thus, it can be summarized that the 2013 Curriculum is a development from the previous curriculum, namely KTSP, in which the K13 curriculum not only emphasizes managing student competencies but also character building. According to the core competencies (KI) that have been determined by the Ministry of Education and Culture, KI-1 and KI-2 are related to the purpose of forming student character while KI-3 and KI-4 are concerned with mastering student competencies.

Based on the explanation above, the problem that will be discussed in this paper is: what is the role of the principal in implementing the 2013 curriculum-based learning at SMP Negeri 6 Unggul Sekayu Musi Banyuasin Regency? Meanwhile, the purpose of this paper is to determine the role of the principal in implementing 2013 curriculum-based learning at SMP Negeri 6 Unggul Sekayu, Musi Banyuasin Regency.

\section{METHODS}

This research used the descriptive qualitative method. [21] states that descriptive qualitative is research that provides an accurate description of a particular individual or group of conditions and phenomena that occur. Data collection was carried out through observation, interviews, and documentation. The samples involved in this research are the principal, teachers, and students of SMP Negeri 6 Unggul Sekayu, Musi Banyuasin Regency. Data were analyzed through four stages; data collection, data reduction, data display, and drawing conclusions [22].

\section{RESULTS AND DISCUSSION}

From the research, it is found that SMP Negeri 6 Unggul Sekayu performed quality mapping through School Self-Evaluation (Evaluasi Diri Sekolah/EDS) which was carried out by all school members. The results of quality mapping through EDS are divided into three stages. First, making EDS results as a reference in determining the vision, mission, and school policies in improving the quality of education. Second, the preparation of a plan to fulfill/improve the quality of education determined in the school development planning and action plan. Third, the implementation of the quality improvement plan for a certain period (semester or academic year).

Based on the results of interviews with the principal of SMP Negeri 6 Unggul Sekayu, the 2013 CurriculumBased Learning Implementation program has long been implemented at SMP Negeri 6 Unggul Sekayu due to intense competition in efforts to improve quality.

Based on the data results through interviews, observation and documentation, it can be concluded that the quality of learning at SMP Negeri 6 Unggul Sekayu is in good condition. The quality of learning at SMP Negeri 6 Unggul Sekayu has met the minimum criteria for the learning process standard based on the National Education Standards including learning planning, learning implementation, and learning evaluation. The achievement of the high quality standard of learning that has been achieved by SMP Negeri 6 Unggul Sekayu is supported by adequate learning facilities and resources as well as high competent teaching resources and teaching staff. The results can be seen from the various kinds of awards and achievements that have been accomplished by students of SMP Negeri 6 Unggul Sekayu.

The vision and mission are used as guidelines and guidelines for every decision taken by the school in formulating goals that will be achieved within a predetermined time. Based on this vision, the principal 
of SMP Negeri 6 Unggul Sekayu formulated a plan for a program to improve the quality of learning standards. The quality standards of learning that have been set by the principal are also expected to encourage teachers to improve their competence in meticulous preparation and planning, carry out an effective learning process, and conduct objective assessments.

Apart from that, the role of the principal in implementing the 2013 Curriculum in the research field is to define programs through the vision and mission of the school. For the 2013 Curriculum-Based Learning Implementation program through the vision and mission of the school to run optimally, the principal of SMP Negeri 6 Unggul Sekayu attempted to realize the 2013 Curriculum-Based Learning Implementation Program into the vision and mission of the school along with all school members based on their respective responsibilities.

Based on the results of the interview, the principal of SMP Negeri 6 Unggul Sekayu admitted that through the vision and mission that they had agreed upon, SMP Negeri 6 Unggul Sekayu runs programs to improve the quality of learning. The vision and mission are used as guidelines for every decision taken by the school in formulating objectives that will be achieved within a certain period. Based on this vision, the principal formulated program planning for improving the quality of learning standards.

It was also found that efforts to increase the professionalism of teachers at SMP Negeri 6 Unggul Sekayu were conducted by the principal, one of which was by creating a development program for teachers in their teaching ability into a strategic program of improvement/development of teachers and educational personnel, including improving the ability to manage classrooms, the 2013 Curriculum development program, classroom action research for teachers at SMP Negeri 6 Unggul Sekayu, monitoring, supervision, evaluation, reports, and follow-up.

In teacher competence, SMP Negeri 6 Unggul Sekayu plans early year training, the 2013 Curriculum workshops, and assistance in the preparation of syllabus, lesson plans, and other learning tools, as well as weekly, monthly, and annual evaluations. The development of teachers' teaching skills at SMP Negeri 6 Unggul Sekayu has been carefully planned through need analysis of teachers at SMP Negeri 6 Unggul Sekayu. Teacher training consists of long-term planning, and short-term planning in the form of annual planning.

The principal of SMP Negeri 6 Unggul Sekayu School also performed mentoring activities carried out once a year, namely by providing training for teachers and educational personnel regarding the vision and mission of the school, training to create learning administration, and the 2013 curriculum development workshop. In addition to motivating teachers, the principal also awarded teachers who were considered to have achievements in the academic field.

In developing teaching ability of teachers, the principal of SMP Negeri 6 Unggul Sekayu considered the importance of enhancing the qualifications and competencies set by the Government, even exceeding the minimum target so that SMP Negeri 6 Unggul Sekayu can earn more scores than standards. Currently, some teachers of SMP Negeri 6 Unggul Sekayu are encouraged by the principal to upgrade their academic qualifications in which those who still have an undergraduate educational qualification are encouraged to enroll in the postgraduate program.

Based on data obtained, it can be seen that efforts to improve the teaching ability of teachers at SMP Negeri 6 Unggul Sekayu were carried out by the principal with a program that has been planned based on the vision and mission of the school, including by sending teachers to take part in Professional Education and Training for Teachers (Pendidikan dan Latihan Profesi Guru/PLPG) for those who have met the criteria.

Further, the findings also show that the principal also played an important role in creating a learning climate that supports the successful implementation of the 2013 curriculum by creating an effective learning process and evaluation system. Though this aspect is the teacher's authority as the direct implementer in the classroom, the principal acts to motivate and encourage teachers to enhance their creativity in designing learning which has implications for increasing students' involvement and competency while still considering factors that support the realization of an effective learning process. The realization of a conducive school climate at the school level includes the realization of school independence, efforts in customer satisfaction, responsive and anticipated attitudes to school needs, creating a safe and orderly school environment, building a culture of quality within the school, fostering high achievement, cultivating the will to improve, developing good communication, establishing robust teamwork, implementing open management, determining and realizing vision and mission, implementing effective educational staff management, increasing the participation of school members and the community, and, last, establishing a strong accountability framework [23].

The principal actively encouraged teachers to collect, analyze, and review data in order to solve 
learning problems is evidence that data-based problem solving has not been cultivated in SMP Negeri 6 Unggul Sekayu. It is supported by the researcher that one of the duties of the principal is to convince teachers about the need for change towards a better environment.[24] If the principal acts effectively as a leader, in this case as a driving force for teachers, then quality education will be created [11]. In general, based on the results of data collection, it can be concluded that the role of the principal in improving the quality of learning at SMP Negeri 6 Unggul Sekayu is carried out through 1) conducting learning mapping; 2) establishing the 2013 Curriculum-Based Learning Implementation program through the vision and mission of the school; 3) improving the teaching quality of teachers at SMP Negeri 6 Unggul Sekayu; and 4) creating a conducive learning climate for the learning process at SMP Negeri 6 Unggul Sekayu.

\section{CONCLUSION}

The role of the principal is very important in determining the successful implementation of a policy supported by all school components. The principal acts as a driving force for teachers in carrying out their roles in learning activities which in turn creates an atmosphere or climate that improves learning outcomes and student quality. From the results of the research, it can be found that the role of the principal in implementing the 2013 Curriculum-based Learning is exhibited through 1) mapping the quality of learning through School Self-Evaluation (EDS) which is carried out by all school members; 2) establishing the 2013 Curriculum-Based Learning Implementation program through the school's vision and mission; 3) improving the quality of teacher teaching; and 4) creating a conducive school climate.

\section{REFERENCES}

[1] Damayani, T., Arafat, Y., Eddy, S. (2020). Pengaruh Kepemimpinan Kepala Sekolah dan Motivasi Kerja terhadap Kinerja Guru. Journal of Innovation in Teaching and Instructional Media, 1(1), pp. 46-57.

[2] Fitria, H. (2018). The Influence Of Organizational Culture And Trust Through The Teacher Performance In The Private Secondary School In Palembang. International Journal of Scientific \& Technology Research, 7(7).

[3] Fitria, H., Mukhtar, M., \& Akbar, M. (2017). The Effect of Organizational Structure And Leadership Style on Teacher Performance In Private Secondary School. IJHCM (International Journal of Human
Capital Management), 1(02), 101-112.Technology Research, 7(7).

[4] Nureva, N., \& Melinda, M. (2021). The Influence of Scientific Approach on the Result of Learning Natural Science in Class V SD Negeri 1 Segalamider at Bandar Lampung. Bulletin of Science Education, 1(1), 97-102.

[5] Ponidi, P., Waziana, W., Kristina, M., \& Gumanti, M. (2020). Model of Utilizing Discovery Learning to Improve Mathematical Learning Achievements. Attractive: Innovative Education Journal, 2(1), 4148.

[6] Nureva, N., \& Melinda, M. (2021). The Influence of Scientific Approach on the Result of Learning Natural Science in Class V SD Negeri 1 Segalamider at Bandar Lampung. Bulletin of Science Education, 1(1), 97-102.

[7] Ain, N., \& Kurniawati, M. (2013). Implementasi kurikulum KTSP: Pembelajaran tematik di sekolah dasar. Jurnal Inspirasi Pendidikan, 3(2).

[8] Ruja, I. N., \& Sukamto. (2015). Survey Permasalahan Implementasi Kurikulum Na- Sional 2013 Mata Pelajaran Ilmu Pengetahuan Sosial Sekolah Menengah Pertama Di Jawa Timur. Jurnal Sejarah Dan Budaya, xi(2), 193-199.

[9] Sudarsana, I. K. (2018). Optimalisasi Penggunaan Teknologi Dalam Implementasi Kurikulum Di Sekolah (Persepektif Teori Konstruktivisme). Jurnal Ilmu Pendidikan, 1(1), 8-15.

[10] Asnawan, A. (2021). Enhancement Integrated Quality Management in Islamic Education Institutions. Bulletin of Science Education, 1(1), 42-49.

[11] Townsend, D \& Butterworth. (1992). Your Child's Scholl. New York: A Plime Book.

[12] Wiyani, A. (2013). Manajemen Kelas. Yogyakarta: Ar-Ruzz Media

[13] OECD. (2009). Improving Educational Leadership. Tool Kit.

[14] Logho, A. F. (2016). Peranan Kepemimpinan Instruksional Dalam Pendidikan: Konsep Dan Aplikasinya Dalam Pendidikan di Indonesia. Jurnal Penelitian, 20(1).

[15] Usman, H. (2012). Faktor-faktor yang Mempengaruhi Perilaku Kepala Sekolah dalam Jurnal Tenaga Kependidikan, Vol.2, No.3. 12-21.

[16] Tahir, A. (2014). Kebijakan Publik \& Transparansi Penyelenggaraan Pemerintah Daerah. Cetakan Kesatu. Bandung: Alfabeta CV.

[17] Mulyadi, D. (2015). Prilaku Organisasi dan Kepemimpinan Pelayanan. Bandung: Alfabet 
[18] Wahab, S. A. (2008). Analisis Kebijaksanaan dari Formulasi ke Implementasi Kebijakan Negara. Bumi Aksara Jakarta.

[19] Sukmadinata, N. S. (2009). Landasan Psikologi dan Proses Pendidikan. Bandung: PT Remaja Rosdakarya.

[20] Mulyasa. (2013). Pengembangan dan implentasi pemikiran kurikulum. rosdakarya bandung.

[21] Koentjaraningrat. (2012). Pedoman Penulisan Karya Ilmiah. Bandung: Universitas Pendidikan Indonesia.

[22] Trihastuti, M., Latief, S., \& Kholid, M. R. (2021). The Influence of Teachers' Leadership and Motivation on Social Science Learning Outcomes MA Yahisha Cihampelas Bandung. Bulletin of Science Education, 1(2), 136-144.

[23] Miles and Huberman, (2013). Analisis Data Kualitatif Terjemahan oleh Tjetjeb Rohendi Rohandi. Jakarta : Universitas Indonesia.

[24] Mulyasa. (2011). Manajemen Berbasis Sekolah, Konsep, strategi dan Implementasi. Bandung: PT Remaja Rosdakarya.

[25] Basri, H. (2014). Kepemimpinan Kepala Sekolah. Bandung: Pustaka Setia. 